\title{
Ariosoma-type Leptocephali (Congridae: Bathymyrinae) in the Mentawai Islands region off western Sumatra, Indonesia
}

\author{
Michael J Miller ${ }^{1 *}$, Mikiya Yamaguchi ${ }^{2}$, Sam Wouthuyzen ${ }^{3}$, Jun Aoyama' ${ }^{1}$, Sasanti Suharti ${ }^{3}$, Tao Ma ${ }^{1}$, \\ Tatsuki Yoshinaga ${ }^{2}$, Yuki Minegishi ${ }^{1}$, Tatsuya Kawakami ${ }^{1}$ and Katsumi Tsukamoto ${ }^{1}$
}

\begin{abstract}
Background: Ariosoma-type leptocephali of the congrid subfamily Bathymyrinae are typically present in tropical and subtropical regions where they reach large sizes and are often abundant compared to other taxa. Different morphological species types of these larvae have been documented in the Indo-Pacific region, but few have been matched with their adult species, and their life histories are not known.

Results: A sampling survey for leptocephali off western Sumatra, Indonesia, collected 297 Ariosoma-type leptocephali of at least 12 different species of both the exterillium gut and non-exterillium gut types that could be distinguished using morphological characteristics. These leptocephali were collected at 23 of 24 stations over deep water but were not caught at two stations over the shelf between Sumatra and Java. They were most abundant in the 15- to 50-mm size range, but six species were also collected with sizes of $>140 \mathrm{~mm}$, some of which were undergoing metamorphosis at sizes of 143 to $324 \mathrm{~mm}$. Larvae of Ariosoma scheelei were most abundant, with small larvae of $\leq 25 \mathrm{~mm}$ present near Sumatra and the Mentawai Islands and larger larvae also present offshore. The other abundant larval types, sp. 1 and Ariosoma sp. 7 showed a different tendency with their small larvae being present more offshore, which suggests different spawning locations possibly linked to differing adult habitats or spawning behaviors.

Conclusions: The presence of at least moderately small leptocephali of most of these species suggests that their adults are present in this region, which indicates that there is a high biodiversity of these small benthic eels on the shelf and slope of the Mentawai Islands region off western Sumatra in the eastern Indian Ocean.
\end{abstract}

Keywords: Leptocephali; Larval distribution; Marine eels; Congridae; Indian Ocean

\section{Background}

One of the largest and often most abundant types of eel larvae, called leptocephali, are the Ariosoma-type larvae of congrid eels of the subfamily Bathymyrinae, which have been collected from offshore waters of the world's tropical and subtropical oceans (Smith 1989a; Miller 2002a; Miller and Tsukamoto 2004; Miller et al. 2006b). Adult bathymyrins, however, are mostly small $(<500 \mathrm{~mm})$ nocturnal eels that live in shallow marine habitats or over the deeper continental slope and appear to burrow tail

\footnotetext{
* Correspondence: miller@aori.u-tokyo.ac.jp

${ }^{1}$ Atmosphere and Ocean Research Institute, University of Tokyo, 5-1-5

Kashiwanoha, Kashiwa 277-8564, Japan

Full list of author information is available at the end of the article
}

first into the substrate, but little is known about them (Castle 1968; Smith 1989b). This subfamily includes the five currently recognized genera of Ariosoma, Bathymyrus, Parabathymyrus, Chiloconger, Paraconger, and Kenyaconger (Smith and Karmovskaya 2003).

There are two groups of eels within this subfamily: those with leptocephali like Ariosoma species and those with leptocephali more similar to other congrids (Smith 1989a). Ariosoma-type leptocephali all grow to sizes of at least about $175 \mathrm{~mm}$, and some species can reach up to about $400 \mathrm{~mm}$ (Mochioka et al. 1982, 1991; Smith 1989a; Strehlow et al. 1998; Miller et al. 2006b; 2013). These larvae have one to three horizontal rows of myoseptal pigment (a short vertical line of tiny spots on 
each myoseptum between the myomeres) along the sides of their bodies (Castle 1964, 1968; Blache 1977; Mochioka et al. 1982, 1991; Tabeta and Mochioka 1988; Smith 1989a; Miller and Tsukamoto 2004). As suggested by the morphological features of these larvae, there are two phylogenetically distinct groups of these eels based on mitochondrial DNA (mtDNA) analyses of their leptocephali (Ma 2006), which are represented by larvae that either have a normal gut with the anus located along the ventral surface of the body (non-exterillium) (Smith 1989a; Mochioka et al. 1991) or have a usually quite long (up to $100 \%$ of the body length) exterillium gut that extends freely away from the body (Mochioka et al. 1982; Smith 1989a) as shown in Figure 1.

Most species of the Bathymyrinae are in the genus Ariosoma, and these probably include all nonexterillium-type larvae and some of those with exterillium gut larvae. Fewer species are in the genera Parabathymyrus and Bathymyrus, which like some species of Ariosoma, have exterillium-type larvae (Smith 1989a). Kenyaconger, Chiloconger, and Paraconger are the other genera of the subfamily, and at least Paraconger and Chiloconger contain species with leptocephali that greatly differ from Ariosoma-type larvae by having only a single lateral pigment row similar to many species of the subfamily Congrinae (Smith 1989a). Mitochondrial genome sequences, however, did not suggest that Paraconger is closely related to Ariosoma (Inoue et al. 2010), so the genera with larvae that differ from Ariosoma-type larvae might not actually be true members of the Bathymyrinae. Morphological characters suggest that Kenyaconger may fit within the group with Ariosoma and the two other genera, but this has not been confirmed (Smith and Karmovskaya
2003). For simplicity in this paper, leptocephali in this study are referred to as Ariosoma-type larvae even though they are larvae of at least three genera.

Leptocephali of Ariosoma-type larvae were identified to the species level in the western North Atlantic (Smith 1989a), but there are more genera and species in the Indo-Pacific. So, only a few species of non-exterillium leptocephali were examined at the species level in previous studies (Castle 1964, 1969; Miller et al. 2006b), and only two have been genetically matched with adult species (Ma et al. 2008b). One species that was distinguished as larvae due to its very low range of number of vertebrae is the shallow-water tropical species Ariosoma scheelei (Castle 1964, 1969; Miller et al. 2006b). Other ranges of vertebrae likely include mostly different species in different regions, making definitive identification difficult without a clear understanding of adult species present in each region.

A few species of non-exterillium leptocephali can be quite abundant compared to other species in some areas including subtropical gyres (Miller and McCleave 1994; Miller 1995, 2002a) and in tropical waters such as around Sulawesi Island in the central Indonesian Seas (Miller et al. 2006b), but few studies focused on these types of leptocephali. Castle $(1964,1969)$ provided some information about the distributions and sizes of a few species or types in the western South Pacific and eastern Indian Ocean. Mochioka et al. $(1982,1991)$ reported on morphological characteristics and geographic occurrences of Ariosomatype leptocephali in the western Pacific region, but recent studies on assemblages of leptocephali in the Indo-Pacific, except for Miller et al. (2002), did not report species/typelevel data for Ariosoma-type leptocephali (Wouthuyzen

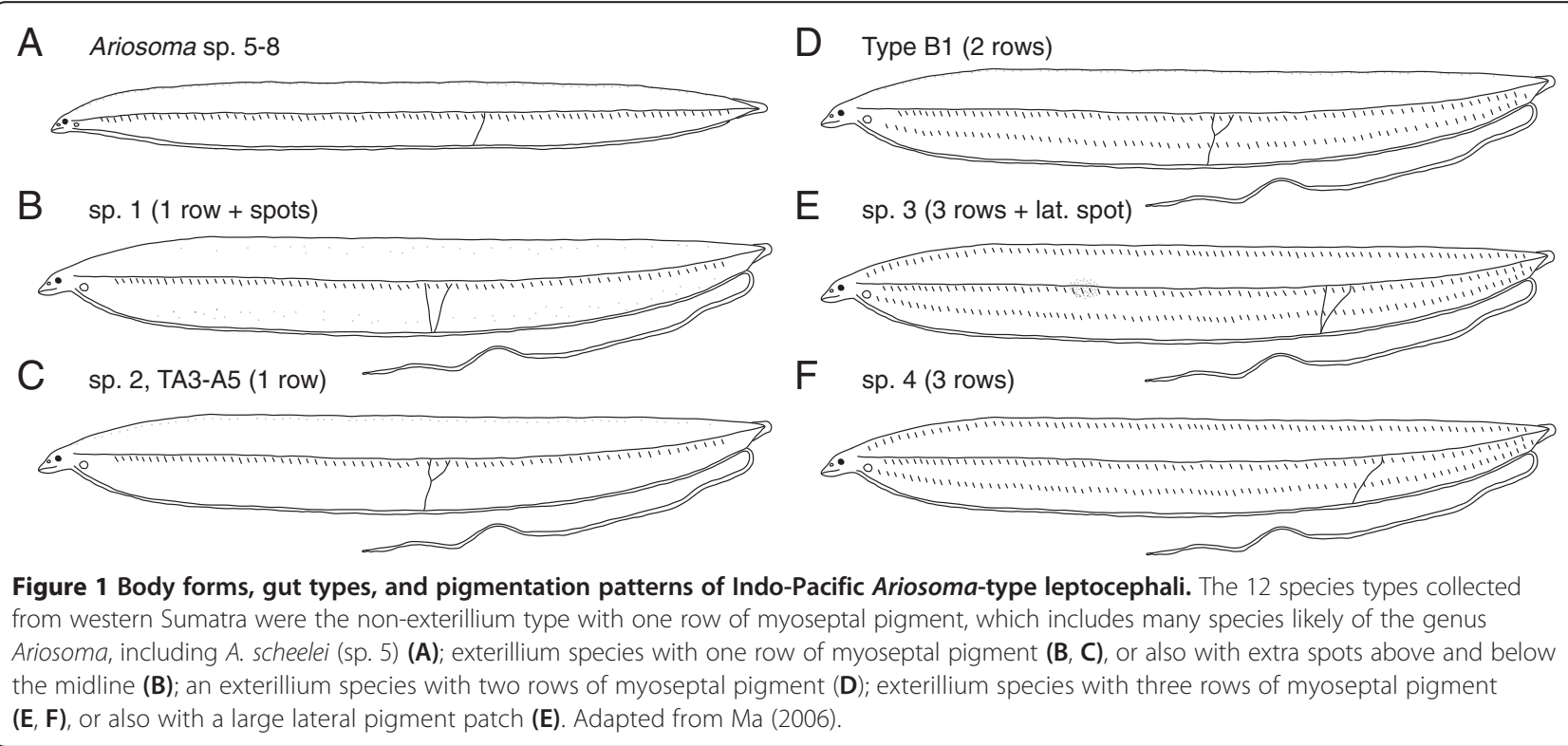


et al. 2005; Miller et al. 2006a), so information is lacking about the distributions and life histories of these species.

The present study examined the species type composition, distribution, and size of Ariosoma-type leptocephali collected during a sampling survey in the Mentawai Islands region off western Sumatra that collected many species of this type of leptocephali. The objectives of this study were to document the possible diversity of this group of marine eels in this area based on the presence of their larvae, briefly examine the life history implications of these catches, and provide information that can be useful for future genetic identification studies to match larvae with their adults for Ariosoma-type leptocephali.

\section{Methods}

Leptocephali were sampled at 25 stations (stns.) during the BJ-03-2 cruise of the R/V Baruna Jaya VII (Research Center for Oceanography of the Indonesian Institute of Sciences) in the eastern Indian Ocean off the western coast of Sumatra, Indonesia on 5 to 21 June 2003 (Figure 2). Sampling at each station consisted of two tows of an Isaacs-Kidd midwater trawl (IKMT) with a mouth opening or $8.7 \mathrm{~m}^{2}$ and a $0.5-\mathrm{mm}$ mesh size. At each station, the IKMT was deployed at night in an oblique tow and a step tow (five horizontal sampling layers), both of which sampled the upper $200 \mathrm{~m}$ (see Aoyama et al. 2007 and Miller et al. 2011a for details). An extra tow was made at stn. 15 (stn. 15B), and all the stations were located in areas with water depths of $>1,500 \mathrm{~m}$, except for stns. 1, 24, and 26 .

Ariosoma-type leptocephali were identified by first categorizing them as having an exterillium gut or not and then matching them to specific types designated by Tabeta and Mochioka (1988) (sp. 1 to sp. 8) and Mochioka et al. (1982) for some rare species (type A3, A4, A5, and B1). Non-exterillium types have only one row of myoseptal pigment, whereas exterillium types can have one, two, or three rows of myoseptal pigment (Figure 1). Two exterillium types also had randomly

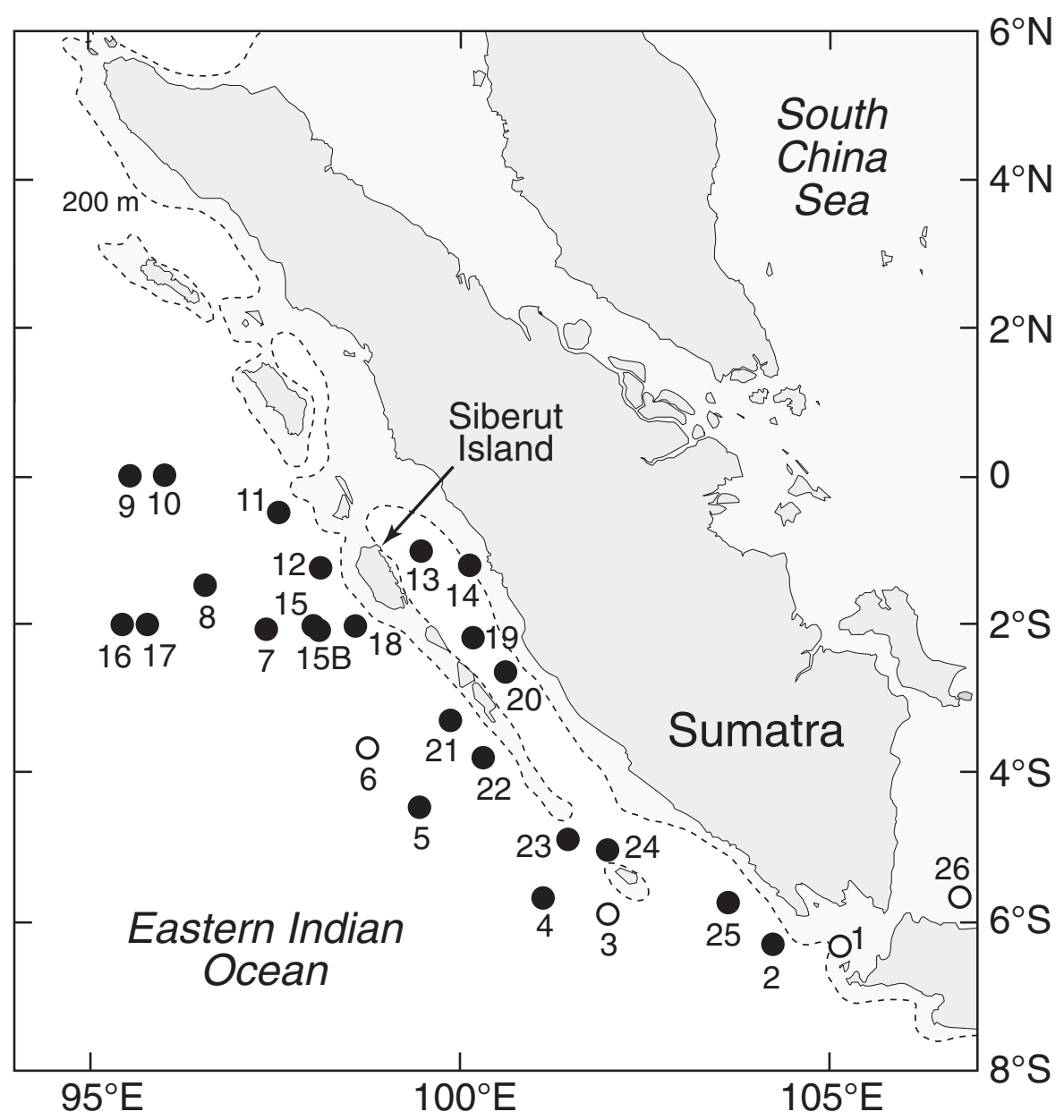

Figure 2 Map showing sampling locations and station numbers during the $\mathbf{B J}-\mathbf{0 3 - 2}$ cruise in June $\mathbf{2 0 0 3}$. Filled circles are stations where Ariosoma-type leptocephali were collected, and open circles are stations were none were leptocephali. Siberut Island is one of the largest Mentawai Islands located offshore of western Sumatra. The dotted line and light shading show the 200-m depth contour of the continental shelf. 
spaced small spots above and below the midline (sp. 1) or a large lateral pigment patch (sp. 3). Mochioka et al. (1991) used a different system of names for the types of non-exterillium leptocephali, but we followed Miller and Tsukamoto (2004) and Ma (2006) using sp. 1 to sp. 8 of Tabeta and Mochioka (1988) and the species types of Mochioka et al. (1982) for less common exterillium types. Because non-exterillium species presently appear likely to only be members of the genus Ariosoma (Smith 1989a; Ma et al. 2008b), they are in most cases, such as in Table 1, referred to that genus, but it is known that exterillium gut species of leptocephali can belong to other genera, so these are only referred to as 'sp.' or 'type'.

Species types collected during this cruise were distinguished by a combination of patterns of pigmentation (Figure 1) and two meristic counts of myomeres. Briefly, non-exterillium types are mostly only distinguishable by the total myomere count (TM) and the myomere count of the position of the last vertical blood vessel (LVBV). These counts for non-exterillium Ariosoma leptocephali of sp. 5, considered to be A. scheelei (TM 108 to 128, LVBV 53 to 63 ), sp. 6 (127 to 134,64 to 72$)$, sp. 7 (136 to 150,71 to 77 ), and sp. 8 (158 to 162,81 to 85 ) (Mochioka et al. 1991, western North Pacific ranges) did not overlap much, which enabled separation of the types (Figure 3). Exterillium types have one row (myoseptal pigment) and small spots above and below in sp. 1 (129 to 141,61 to 66 ); one row in sp. 2 (131 to 137,62 to 67 ); three rows and a large lateral pigment patch in sp. 3 (146 to 155,89 to 103 ); three rows in sp. 4 (148 to 161 , 89 to 103) (Tabeta and Mochioka 1988), or just one row in types A3 (145 to 151,68 to 79 ), A4 (160 to 173,78 to
91), and A5 (171 to 177,101 to 104$)$; and two rows in type B1 (151 to 154,80 to 88 ) (Mochioka et al. 1982). The larvae classified as type A5 had a lower range of TM compared to those of Mochioka et al. (1982), but their LVBV counts were higher than those of type A4.

Among these 12 species types, only 1 (sp. 5) could be identified as likely being leptocephali of $A$. scheelei, a small tropical eel, the larvae of which are also very abundant in central Indonesian seas (Miller et al. 2006b). It was listed as Ariosoma sp. 5 by Tabeta and Mochioka (1988) and as type I by Mochioka et al. (1991), but both were suggested to be $A$. scheelei. Castle (1968) noted that this species has a very low number of vertebrae/myomeres, so because no other Ariosoma species appears to have such a low range of vertebrae, the species identification of sp. 5 leptocephali as $A$. scheelei seems certain and that species name was used in the present study.

During the BJ-03-2 cruise, the total length (TL) of leptocephali was measured to the nearest $0.1 \mathrm{~mm}$, and they were tentatively identified on board the ship before they were preserved in 10\% formalin seawater or $99 \%$ ethanol. Formalin-preserved specimens were later reexamined in the laboratory, and the myomere counts were made on specimens that were not damaged. Myomere counts of specimens preserved in ethanol were counted on board the ship, and these specimens were later examined genetically by sequencing about 1,300 sites of their mtDNA $16 \mathrm{~S}$ ribosomal RNA in the study of Ma (2006) (see Ma et al. 2008a for details of the sequencing analyses). Catch rates of the two size categories of $\leq 25$ and $>25 \mathrm{~mm}$ were calculated using the number of larvae caught in both tows at a station and the volume of water filtered by the net during

Table 1 Number of each species or type of Ariosoma-type leptocephali collected off western Sumatra

\begin{tabular}{|c|c|c|c|c|c|c|c|}
\hline Species/type & Gut & TM & LVBV & DNA study ${ }^{a}$ & Number of stns. & Size range (meta) & Total \\
\hline Ariosoma scheelei & N-EX & $110-125$ & $50-61$ & 9 & 22 & $10.6-175.0$ & 114 \\
\hline Ariosoma sp. 6 & N-EX & 130-136 & $61-71$ & 1 & 5 & $15.1-79.4(197.0)$ & 8 \\
\hline Ariosoma sp. 7 & N-EX & $138-149$ & $70-74$ & 2 & 12 & $12.1-220.0(202.2-324.0)$ & 44 \\
\hline Ariosoma sp. 8 & N-EX & $157-164$ & $80-85$ & & 3 & $22.2-34.4$ & 4 \\
\hline sp. 1 & EXT & 130-144 & $56-69$ & 6 & 13 & $13.5-181.0$ & 50 \\
\hline sp. 2 & EXT & $132-143$ & $60-70$ & 2 & 9 & $16.0-60.4$ & 21 \\
\hline sp. 3 & EXT & 151-155 & $91-99$ & 3 & 5 & $30.0-158.0$ & 7 \\
\hline sp. 4 & EXT & $150-157$ & $86-107$ & 3 & 8 & $18.2-39.6(143.0)$ & 15 \\
\hline Type A3 & EXT & 149,150 & 79,84 & 1 & 2 & $27.2,50.0$ & 2 \\
\hline Type A4 & EXT & 166 & 78 & 1 & 1 & 141.5 & 1 \\
\hline Type A5 & EXT & $158-164$ & 93-101 & 1 & 1 & $33.4-38.5$ & 3 \\
\hline Type B1 & EXT & 149 & 80 & 1 & 1 & 99.3 & 1 \\
\hline sp. 1 or 2 & EXT & $133-140$ & $61-67$ & & 5 & $(183.5-232.0)$ & 5 \\
\hline sp. & & & & & 11 & $13.2-67.2(>160-205.0)$ & 22 \\
\hline Total number or range & & $110-166$ & $50-106$ & 30 & 22 & $10.6-324.0$ & 297 \\
\hline
\end{tabular}

$N$-EX, non-exterillium; EXT, exterillium; TM, total myomeres; $L V B V$, last vertical blood vessel; stns., stations; meta, metamorphosing larvae. ${ }^{\text {a }}$ Specimens genetically examined by Ma (2006). 

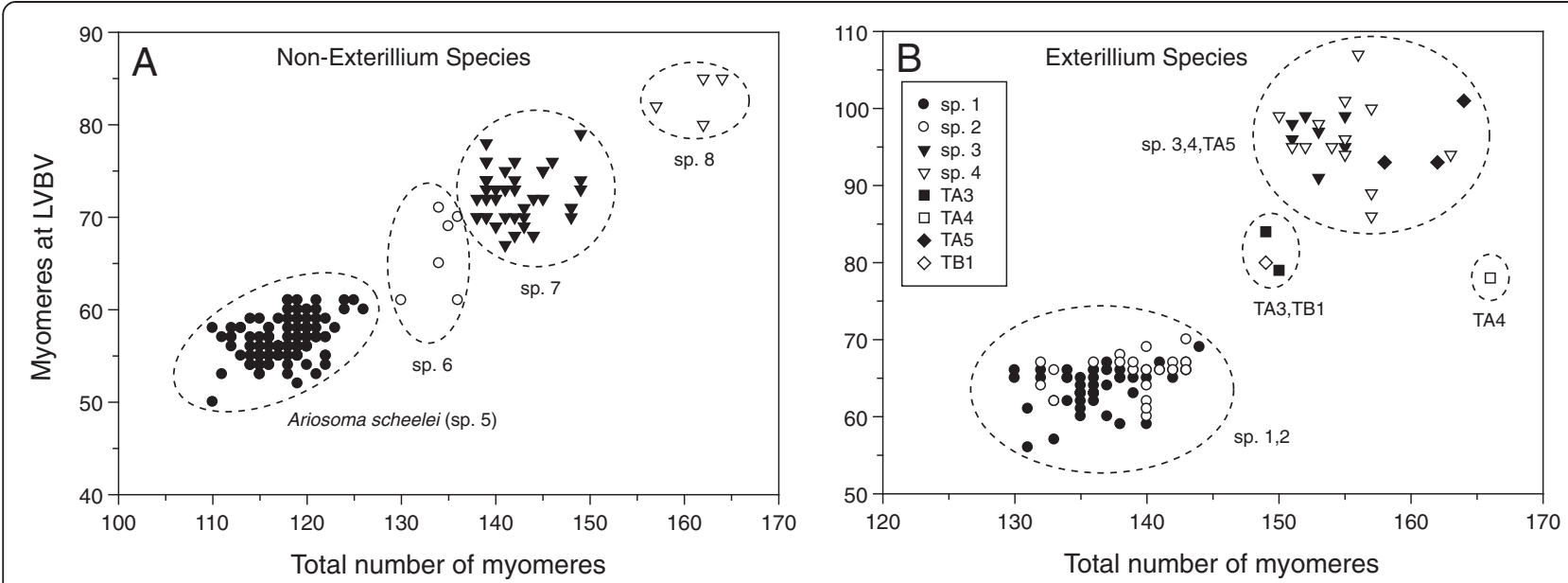

Figure 3 Plots of meristic counts of TM and myomeres at LVBV. Non-exterillium gut (A) and exterillium gut (B) Ariosoma-type leptocephali collected off western Sumatra, with ovals surrounding the species types or groups of species within different TM-LVBV ranges.

both tows, which was estimated from the number of flowmeter revolutions and a calibration factor determined at the end of the cruise.

\section{Results}

\section{Morphological and genetic types}

Morphological characteristics that were examined in the 297 Ariosoma-type leptocephali collected during the BJ-03-2 sampling survey off western Sumatra indicated that there were at least 12 different species present among the larvae (Table 1). This number of species was confirmed by the mtDNA sequence analyses of $\mathrm{Ma}$ (2006) who found that there were at least 11 species among the larvae sequenced (Ariosoma sp. 8 was not among the 30 leptocephali preserved in ethanol) which corresponded to the morphological species types (Table 1).

In total, 170 of the leptocephali were morphologically distinguished as non-exterillium types of Ariosoma larvae, with $A$. scheelei (sp. 5) being most abundant $(n=114)$, followed by sp. $7(n=44)$, sp. $6(n=8)$, and sp. $8(n=4)$ (Table 1). There were 105 exterillium-type leptocephali, with sp. $1(n=50)$, sp. $2(n=21)$, and sp. $4(n=15)$ being most abundant, with only 1 to 7 leptocephali of the other exterillium species.

Plots of TM vs. LVBV of the leptocephali showed that non-exterillium species types defined using the TM and LVBV ranges of Mochioka et al. (1991) did not overlap in the distributions of their TM-LVBV points (Figure 3A). Their overall TM counts ranged over about 55 myomeres (110 to 164), with their LVBV counts ranging over 36 myomeres (50 to 85 ,) and being linearly related to the TM $\left(r^{2}=0.9\right.$, data not shown). The distribution of points suggested that some of the Ariosoma sp. 6 larvae with high LVBV counts could actually be Ariosoma sp. 7 larvae.
TM and LVBV points of leptocephali of exterillium species overlapped in three areas of the plot (Figure 3B). In the lower range, sp. 1 and sp. 2 overlapped, as did sp. 3, sp. 4, and type A5 in the higher range; and types A3 and B1 were also tightly clustered. Differences in pigmentation patterns were used to distinguish those species with overlapping meristic counts. Type A4 had a low LVBV count relative to its TM count. The TM of the exterillium-type leptocephali were also linearly related to their LVBV, except for within the abundant species and for type A4 $\left(r^{2}=0.8\right.$, data not shown). The exterillium species were spread out across a higher, narrower range of TM of about 37 myomeres (130 to 166) with wider ranges of TM compared to their LVBV counts within sp. 1 and 2. However, their range of LVBV counts of 51 myomeres (56 to 106) was wider than that of non-exterillium species.

\section{Distribution, size, and abundance}

Most Ariosoma-type leptocephali collected in the Mentawai Islands region were in the $15-$ to $50-\mathrm{mm}$ size range, although $A$. scheelei was also present in the 120- to 175 $\mathrm{mm}$ size range (Figure 4) up to its likely maximum size (Miller et al. 2006b). Several species including Ariosoma sp. 7 were collected at sizes of $>175 \mathrm{~mm}$, and most of those were undergoing metamorphosis (Figure 4; see below).

Ariosoma-type leptocephali were collected at all of the stations except for stn. 6 offshore and stns. 1 and 26 that were over the continental shelf between Sumatra and Java (Figures 2, 5, and 6). The distributions of smallersized leptocephali of $\leq 25 \mathrm{~mm}$ showed differing patterns for some of the common species. Small larvae of A. scheelei had the highest catch rates inshore of Siberut Island and near the southernmost Mentawai Islands, 


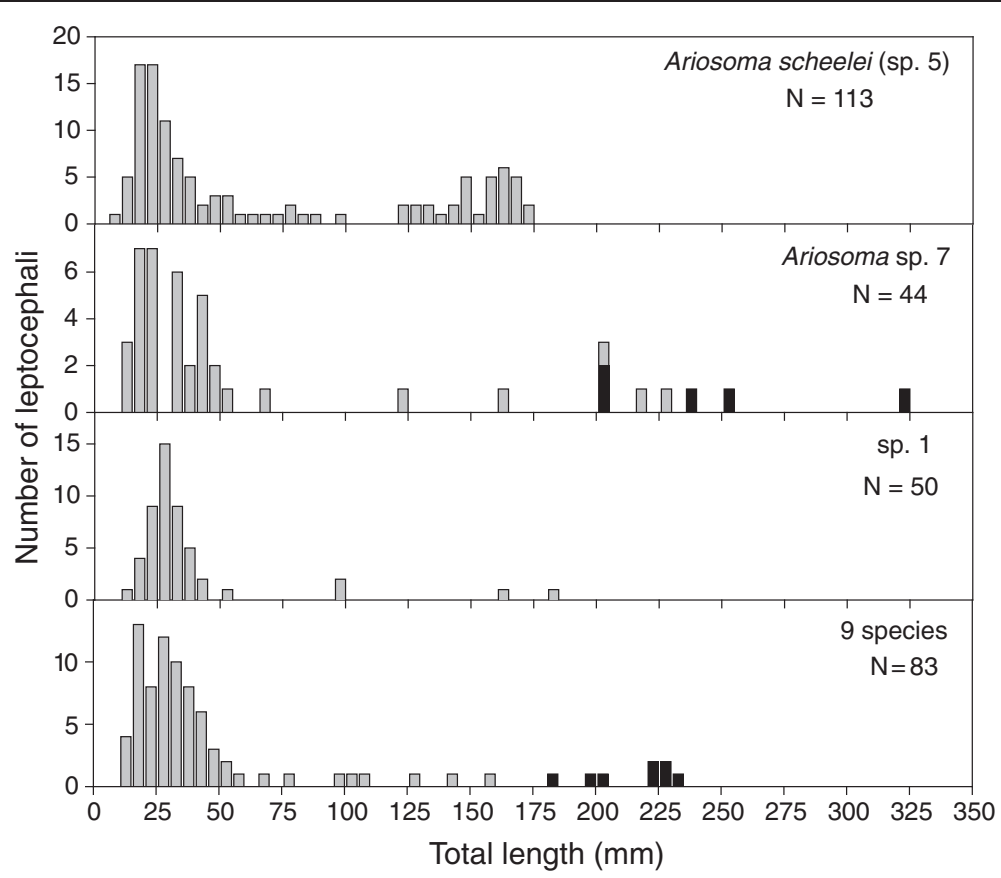

Figure 4 Length-frequency distributions of leptocephali of Ariosoma-type leptocephali collected off western Sumatra. The three most abundant species and the remaining nine species pooled together are plotted, with black bars showing metamorphosing leptocephali.

whereas catch rates of sp. 1 and Ariosoma sp. 7 were highest at more-offshore stations and were almost completely absent from areas closest to the coast of Sumatra (Figure 5). Smaller larvae of $\leq 25 \mathrm{~mm}$ of other species or those that were not identified to a species type were restricted to ten stations, mostly near the islands or inshore of them. The smallest larvae of $<15 \mathrm{~mm}$ were collected at only seven stations near the islands except for a $12.1 \mathrm{~mm}$ Ariosoma sp. 7 larva that was caught at stn. 8 (Figures 1 and 5).

Larger leptocephali of $>25 \mathrm{~mm}$ also showed some differences in distributions among species. Large A. scheelei were caught at almost all stations over deep water except for two stations, and they had high catch rates at several offshore stations (Figure 6). Other species were more randomly distributed at some stations, but not others.

\section{Metamorphosing leptocephali}

There were 15 metamorphosing leptocephali (distinguished by loss of teeth and thickening of the head and body) collected at 11 stations, which were all $>175 \mathrm{~mm}$ in size (Table 1, Figure 4). Almost $1 / 2$ were caught at stns. 23 to 25 in the southern part of the study area (Figures 2 and 6), and 1 was caught at stn. 17 offshore. These included five Ariosoma sp. 7 (202.2 to 252.5 and $324.0 \mathrm{~mm}$ ), five sp. 1 or sp. 2 (183.5 to $232.0 \mathrm{~mm}$ ), one sp. $4(230.0 \mathrm{~mm})$, one Ariosoma sp. $6(197.0 \mathrm{~mm})$, and three unidentified specimens ( $>160$ to $205.0 \mathrm{~mm}$ ). These metamorphosing larvae were caught at a few stations throughout the study area except for the northernmost stations (Figure 6). No metamorphosing A. scheelei leptocephali were detected, although the upper size class was large enough to undergo metamorphosis based on collections of A. scheelei larvae around Sulawesi Island to the east in the central Indonesian Seas (Miller et al. 2006b). This may have been due in part to the fact that $64 \%$ of the larvae of $>120 \mathrm{~mm}$ of this species were caught in further offshore stations in the northwestern region of the study area that were not close to their recruitment habitats.

\section{Discussion}

This study found that there were at least 12 different species of exterillium and non-exterillium Ariosomatype leptocephali collected off western Sumatra in June 2003. The meristic counts of TM and LVBV used in combination with pigmentation patterns made it possible to distinguish these species according to previously described characteristics and meristic ranges (Mochioka et al. 1982, 1991; Tabeta and Mochioka 1988). The plots of TM and LVBV showed that meristic relationships among the species types within the two groups of leptocephali differed some because non-exterillium species had a wider TM range, but exterillium species had a wider range of LVBV counts. Pigmentation patterns were essential to separate the different species of exterillium-type larvae due to their overlapping meristic counts. 


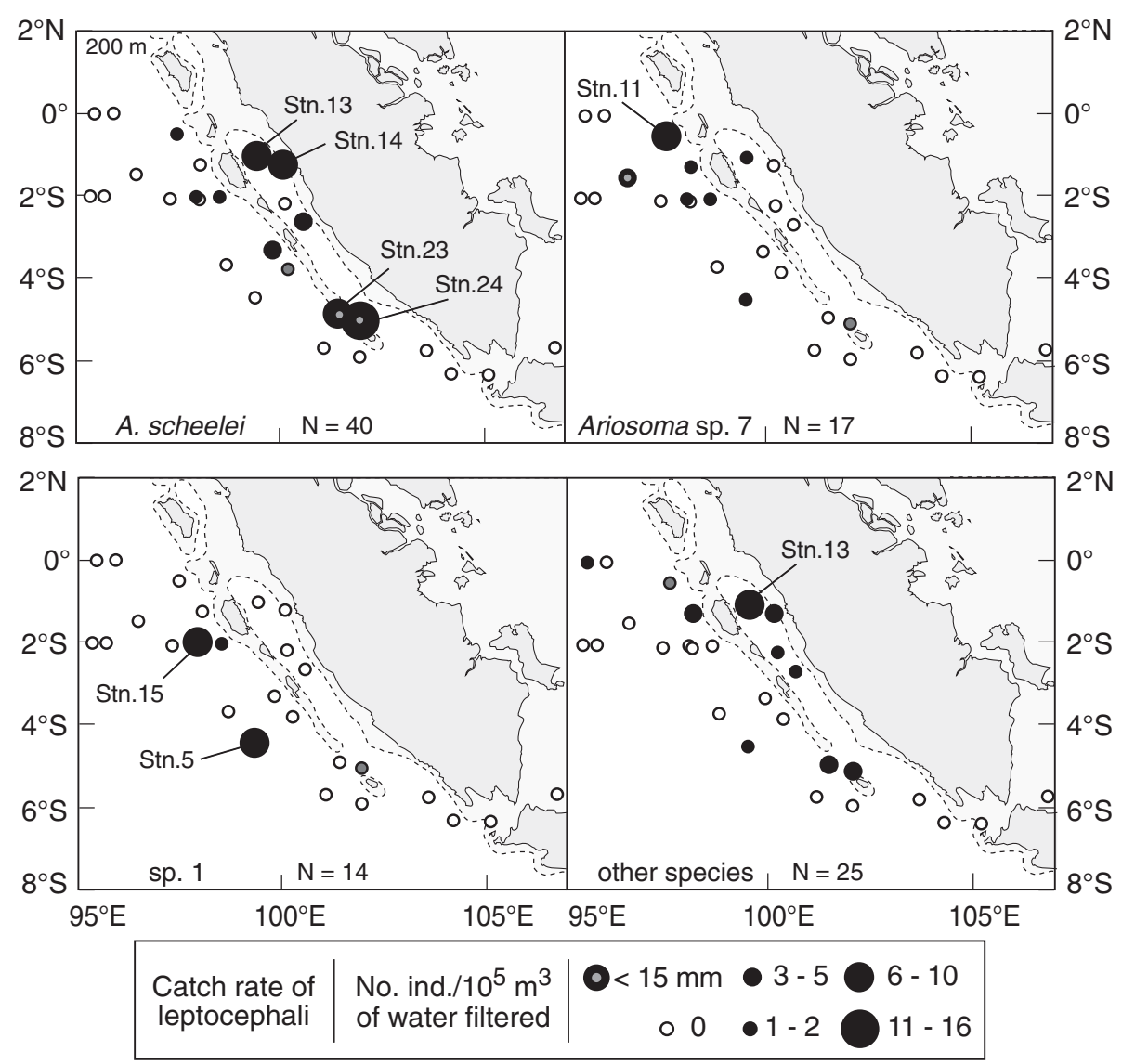

Figure $\mathbf{5}$ Catch rates of leptocephali of $\leq \mathbf{2 5} \mathbf{~} \mathbf{m}$ in length collected off western Sumatra. Three species of Ariosoma-type leptocephali and other species pooled together are plotted, with catch locations of smaller leptocephali of $<15 \mathrm{~mm}$ shown with a gray dot inside the catch-rate symbols. Stations with the highest catch rates are labeled for comparison with the text.

Each of the morphological species types plotted in Figure 3 was genetically confirmed to be distinct species (Ma 2006), except for Ariosoma sp. 8, which was not sequenced. However, Ariosoma sp. 7 and sp. 3 included two species or mtDNA lineages (Ma 2006). Considering that the meristically distinct Ariosoma sp. 8 larvae are quite likely to also be a distinct species, there were at least 12 species and as many as 14 present among the leptocephali collected in this area during the survey of the Mentawai Islands region off western Sumatra.

Only five species of these leptocephali were common during the sampling survey in terms of numbers collected and the number of stations where they were collected (A. scheelei, and Ariosoma sp. 7, sp. 1, sp. 2, and sp. 4), and these larvae were most abundant in a smaller size range $(<60 \mathrm{~mm})$. A. scheele $i$ was the most abundant species off western Sumatra, and it was also the most abundant species of Ariosoma-type leptocephali in the central Indonesian Seas in May 2001 in a similar IKMT survey (Wouthuyzen et al. 2005; Miller et al. 2006b). It also seems to be an abundant species in the western South Pacific and western Indian Ocean, and it spawns off southern Java in the eastern Indian Ocean (Castle 1968), where its larvae were collected during multiple surveys (Castle 1969). Ariosoma sp. 7 was the second most abundant non-exterillium species off western Sumatra. This type of larvae in the western North Pacific belongs to Ariosoma major (Ma et al. 2008a) and is abundant offshore in the subtropical gyre (M) Miller et al., unpublished data). Off Sumatra, however, these sp. 7 larvae probably belong to Ariostoma mauritianum or possibly another species as discussed below, because $A$. major is thought to only be distributed in the East China Sea and Japan region (Asano 1984). Ariosoma balearicum appears to be an abundant eel at depths of 30 to $50 \mathrm{~m}$ along the southeastern coast of the USA (Walsh et al. 2006), and its leptocephali are also abundant offshore (Miller 1995, 2002a). It is unclear if the relative abundances of each species of leptocephali that were collected off Sumatra are directly related to the abundance of the adults in this region, but it is a possibility.

The 12 to 14 species found morphologically and genetically in the collections of Ariosoma-type leptocephali off western Sumatra corresponded well with the 14 species 


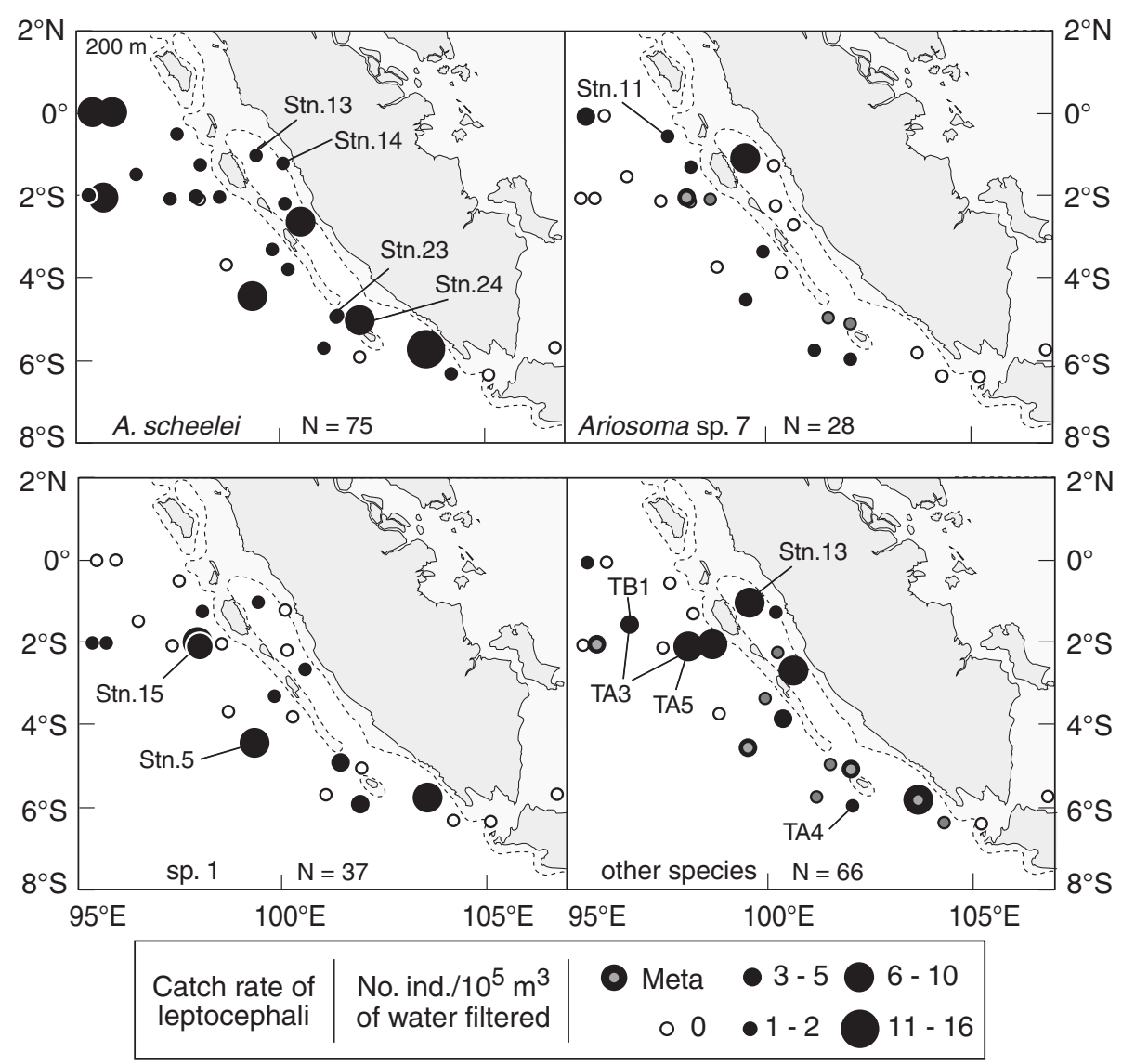

Figure $\mathbf{6}$ Catch rates of leptocephali of $>\mathbf{2 5} \mathbf{~} \mathbf{m m}$ in length collected off western Sumatra. Three species of Ariosoma-type leptocephali and other species pooled together are plotted, with stations where metamorphosing leptocephali were collected shown with a gray dot inside the catch rate symbols. Stations with the highest catch rates of small leptocephali are labeled for comparison with Figure 5, and stations where the four rare species types were collected are also labeled.

of adult Ariosoma (8 species), Bathymyrus (2), Parabathymyrus (3), and Kenyaconger (1) listed as being present either in the Indian Ocean or in the Indo-Pacific and the Indo-West Pacific region in general (widely distributed species) in FishBase (Froese and Pauly 2000; accessed 15 November 2012). All of these species could be present in the eastern Indian Ocean, considering that these larvae grow for many months reaching large sizes, and they could be transported long distances by ocean currents. It is well documented that water from the Indonesian Seas flows into the eastern Indian Ocean (Hautala et al. 2001; Vranes et al. 2002), and equatorial current jets can transport water in both directions across the northern Indian Ocean (Thompson et al. 2006; Sengupta et al. 2007; Kantha et al. 2008). This makes it likely that some species reported to be present as juveniles or adults in western Indonesia, the South China Sea, or the western Indian Ocean could also be present off western Sumatra.

Except for A. scheelei and possibly the presence of A. mauritianum, it is premature to attempt to determine possible species matches between adult species and larval types in the eastern Indian Ocean with any certainty because of a lack of adequate data on geographic distributions and total numbers of vertebrae (TV) data for adults of most species. However, several species known from the area or the regions adjacent to the study area show potential matches with the TM ranges in Figure 3. A. scheelei is an abundant shallow-water tropical species with a lower TV range (Castle 1964, 1968), so the identification of Ariosoma sp. 5-type leptocephali seems certain as previously concluded (Miller et al. 2006b). A. mauritianum (TV, 143) fits Ariosoma sp. 7 larvae (138 to 149), and Ariosoma sokotranum (136 to 141; western Indian Ocean) (Karmovskaya 1992) also fits the lower TM range of Arioso$m a$ sp. 7. Castle (1964) considered non-exterillium leptocephali with TM of 134 to 153 in the western South Pacific and those with 130 to $145 \mathrm{TM}$ in the northwestern Indian Ocean (Castle 1975) to be larvae of A. mauritianum. Castle (1969) reported on the distribution and size of these larvae along a latitudinal transect of stations at $110^{\circ} \mathrm{E}$ that was sampled in multiple seasons in the eastern Indian Ocean. But, leptocephali with the TM range of $A$. mauritianum 
may consist of more than one species, and this appears to be the case in the eastern Indian Ocean as indicated by the mtDNA sequencing of Ma (2006) of two specimens of Ariosoma sp. 7 from the present study and the TV ranges of two of the adult species that could be present.

For exterillium larvae, Parabathymyrus karrerae (TV 156 to 160 , western Indian Ocean) fits within the high-TM group of larvae including sp. 3, sp. 4, and type A5 (Karmovskaya 1992). Bathymyrus smithi (150 to 155, Mozambique, southern Indonesia) (Castle 1968) fits the TM ranges of type A3 and B1 or the lower TM range of the higher-LVBV exterillium group, as does Ariosoma ophidiophthalmus (150 to 153, western Indian Ocean) (Karmovskaya 1992). If Parabathymyrus brachyrhynchus (166 to 168) (Smith 1989b) has a species range extending further south from the Philippines, it matches the high TM count of type A4. P. macrophthalmus (131 to 134, Japan, South China Sea, and Indonesia) (Hatooka 2000) fits within the lower TM ranges of sp. 1 and sp. 2. Other species reported from the western Indian Ocean, including Ariosoma nigrimanum, Ariosoma bauchotae, Bathymyrus echinorhynchus, Ariosoma faciatum (Indo-Pacific), and Ariosoma anago (149 to 159, Asano 1984) (Indo-West Pacific), could also possibly be present off western Sumatra (FishBase).

Trawling surveys in this region of the eastern Indian Ocean only reported collections of three species of bathymrid eels of $A$. mauritianum, A. anago, and B. smithi (Gloerfelt-Tarp and Kailola 2006). However, at least some Ariosoma eels are adapted for tail-first burrowing in soft sediments (Smith 1989b; MJ Miller personal observation), so they might not be vulnerable to trawling if they are hiding in the sediment during the day, or they may be able to avoid capture by burrowing when an approaching trawl is detected at night. This is similar to the situation in which these trawl surveys only collected one species of garden eel (Congridae: Heterocongrinae) (Gloerfelt-Tarp and Kailola 2006), which are species that live in burrows, but nine species of garden eel leptocephali were collected in the same survey as the present study (Miller et al. 2011a). Trawling may also be difficult to conduct in various shallow-water habitats with coral structures or other debris where many of these congrid eels live.

Although the actual species level composition of bathymyrid leptocephali could not be determined in the present study, it appears that the region around the Mentawai Islands has a high diversity of this group of congrid eels. Considering that 7 of the 12 species of larvae were collected in this area at sizes of $<25 \mathrm{~mm}$, and 3 others were collected at 27 to $33 \mathrm{~mm}$ (Table 1), it is likely that they were spawned nearby and that juveniles and adults of many of these species live in this area. In comparison, nine species of Ariosoma-type leptocephali were collected around Sulawesi Island in the central Indonesian Seas (Wouthuyzen et al. 2005), but only a minimum of four were reported from the western South Pacific (Miller et al. 2006b). In total, five species were described from the entire western North Atlantic (Smith 1989a), and Blache (1977) described three species from the Gulf of Guinea. The nine species of garden eel leptocephali that were collected off Sumatra in the sampling of the present study is a high proportion of garden eel species known from the Indo-Pacific (Miller et al. 2011a), which also suggests that there is a high biodiversity of various types of congrid eels in this region. Garden eel leptocephali were differently distributed compared to Ariosomatype leptocephali, with many garden eel larvae appearing to have been transported offshore from just north of Siberut Island (Miller et al. 2011a).

Patterns of distribution and sizes of Ariosoma-type leptocephali in the present study suggest there are some different life history characteristics among these bathymyrin species. The more-inshore distribution of small larvae of A. scheelei compared to those of Ariosoma sp. 7 and sp. 1 suggests the possibility of different spawning locations in relation to the shelf and slope. This could be related to different depth distributions of the adults or different movements before spawning. For example, A. scheelei and $A$. balearicum can be present in very shallow water that is mostly $<100 \mathrm{~m}$, but $A$. selenops and B. smithi were collected at 220 to 549 and 470 to $490 \mathrm{~m}$ depth ranges, respectively (Castle 1986; Smith 1989b). At least a few species of Ariosoma may also make short spawning migrations (Miller 2002a), and some species of Conger eels are known to migrate to spawn offshore (McCleave and Miller 1994; Miller et al. 2011b). Although eels such as garden eels and moray eels may spawn within shallow-water habitats (Moyer and Zaiser 1982; Thresher 1984; Ferraris 1985), little is known about the reproductive ecology or species distributions of most marine eels including those of the Bathymyrinae (Miller 2002b, 2009).

The distribution and abundance patterns of the leptocephali in the present study provided no clear information about their spawning locations or larval transport patterns possibly because spawning by each species may occur locally and not in specific spawning areas. Ocean currents and eddy patterns in this region are likely to be complex, making it difficult to estimate larval transport patterns. Surface currents inshore of the Mentawai Islands are thought to be to the southeast parallel to the coast of western Sumatra (Wyrtki 1961), and large eddies move past western Sumatra (Hacker et al. 1998; Vinayachandran et al. 1999; Iskandar et al. 2006). Upwelling sometimes occurs off the coast of western Sumatra that would transport surface water offshore (Susanto et al. 2001). In addition, strong eastward equatorial jets lasting about 10 to 20 days typically occur during May to the northwest of the study area (Thompson et al. 2006; Sengupta et al. 2007; Kantha et al. 2008), which could have a major effect on the 
variability of currents and eddies around the Mentawai Islands. These current flows and eddies likely transport leptocephali in a variety of directions during their larval periods in this area.

To better understand the life histories and ecology of these eels and their larvae that grow to large sizes, future research is needed to explore the diversity of species of bathymyrin eels that are present in shelf and slope habitats around the Mentawai Islands and in other parts of the Indo-Pacific. Tissue samples need to be obtained from adult eels that can be used to match Ariosoma-type leptocephali with their adult species in each region. Once the species identities of these interesting larvae that grow to very large sizes are known, catch data of leptocephali can be used to learn about the life histories and larval distributions of these poorly known eels that live on continental shelves and slopes around the world.

\section{Conclusions}

This study found that there were at least 12 different species of exterillium and non-exterillium Ariosoma-type leptocephali that could be morphologically distinguished among the larvae that were collected off western Sumatra in June 2003, and the DNA sequence analyses indicated that there may have been 14 species. Leptocephali of $A$. scheelei were the most abundant, and the adults of this species and most of the other species whose larvae were collected had likely been spawning in the western Sumatra and Mentawai Islands region. A high biodiversity of Ariosoma-type eels appears to be present in this region based on these collections of their larvae, and the number of larval species corresponds with the number of adult species that might be present in the Indian Ocean. A variety of future research is needed to better understand these eels and their leptocephalus larvae.

\section{Competing interests}

The authors declare that they have no competing interests.

\section{Authors' contributions}

MJM, SW, JA, SS, YM, TK, and KT participated in the sampling survey off western Sumatra to collect the leptocephali. MJM, MY, and TY worked on examining the leptocephalus specimens and data. TM analyzed the mtDNA sequences. MJM wrote the paper. All authors read and approved the final manuscript.

\section{Acknowledgements}

We thank the captain, crew, and technicians of the RN Baruna Jaya VII for their help deploying the IKMT and sorting the plankton samples during the survey off western Sumatra. This work was supported in part by grants-in-aid nos. 1299346 and 12NP0201 from the Ministry of Education, Science, Sports and Culture, Tokyo, Japan. KT was supported by the Research Foundation, Touwa Shokuhin Shinkoukai (Tokyo, Japan) and the Eel Research Foundation, Noborikai (Tokyo, Japan).

\section{Author details}

${ }^{1}$ Atmosphere and Ocean Research Institute, University of Tokyo, 5-1-5 Kashiwanoha, Kashiwa 277-8564, Japan. 'Department of Marine Biosciences, School of Marine Biosciences, Kitasato University, 1-15-1 Kitasato Minami Ward, Sagamihara, Kanagawa 252-0373, Japan. ${ }^{3}$ Research Center for
Oceanography, Indonesian Institute of Sciences, Jl. Pasir Putih 1, Ancol Timur, Jakarta 14430, Indonesia.

Received: 3 January 2013 Accepted: 3 May 2013

Published: 4 October 2013

\section{References}

Aoyama J, Wouthuyzen S, Miller MJ, Minegishi Y, Minagawa G, Kuroki M, Suharti SR, Kawakami T, Sumardiharga KO, Tsukamoto K (2007) Distribution of leptocephali of the freshwater eels, genus Anguilla, in the waters off west Sumatra in the Indian Ocean. Environ Biol Fish 80:445-452

Asano H (1984) Congridae, conger eels. In: Masuda H, Amaoka K, Araga C, Uyeno T, Yoshino T (ed) Fishes of the Japanese Archipelago. Tokai University Press, Tokyo, pp 27-29

Blache J (1977) Leptocephales des poissons Anguilliformes dans la zone sud du Golfe de Guinée. Faune Trop 10:1-381

Castle PHJ (1964) Congrid leptocephali in Australasian waters with descriptions of Conger wilsoni (Bl. and Schn.) and C. verreauxi Kaup, vol 37. Zool Publication, Victoria University Wellington, pp 1-45

Castle PHJ (1968) The congrid eels of the western Indian Ocean and the Red Sea. Department of Ichthyology, Rhodes University, Grahamstown South Africa. Ichthyological Bull(33):685-726

Castle PHJ (1969) Species structure and seasonal distribution of leptocephali in the eastern Indian Ocean (110 $\mathrm{E})$. Cah ORSTOM ser Oceanogr 7:53-88

Castle PHJ (1975) Fische des Indischen Ozeans. Ergebnisse der ichthyologischen Untersuchungen während der Expedition des Forschungsschiffes "Meteor" in den Indischen Ozean, Oktober 1964 bis Mai 1965. A. Systematischer Teil, XV. Leptocephali (Anguilliformes) "Meteor". Forschungsergebnisse 21:19-29

Castle PHJ (1986) Congridae. In: Smith MM, Heemstra PC (ed) Smiths' sea fishes. Springer, Berlin, pp 161-165

Ferraris CJ (1985) Redescription and spawning behavior of the muraenid eel Gymnothorax herrei. Copeia 1985:518-520

Froese R, Pauly D (ed) (2000) FishBase 2000: concepts, design and data sources. ICLARM, Los Baños, Laguna, Philippines, p 344

Gloerfelt-Tarp T, Kailola PJ (2006) Trawled fishes of southern Indonesia and northwestern Australia. Australian Development Assistance Bureau, Canberra; Directorate General of Fisheries, Jakarta; German Agency for Technical Cooperation, Eschborn, Germany

Hacker P, Firing E, Hummon J (1998) Bay of Bengal currents during the northeast monsoon. Geophys Res Lett 25:2769-2772

Hatooka K (2000) Congridae, conger eels. In: Nakabo T (ed) Fishes of Japan with pictorial keys to species, 2nd edition. Tokai University Press, Tokyo, pp 227234 (in Japanese)

Hautala SL, Sprintall J, Potemra JT, Chong JC, Pandoe W, Bray N, llahude AG (2001) Velocity structure and transport of the Indonesian throughflow in the major straits restricting flow into the Indian Ocean. J Geophys Res 106:19527-19546

Inoue JG, Miya M, Miller MJ, Sado T, Hanel R, López JA, Hatooka K, Aoyama J, Minegishi Y, Nishida N, Tsukamoto K (2010) Deep-ocean origin of the freshwater eels. Biol Lett 6:363-366

Iskandar I, Tozuka T, Sasaki H, Masumoto Y, Yamagata T (2006) Intraseasonal variations of surface and subsurface currents off Java as simulated in a highresolution ocean general circulation model. J Geophys Res 111:C12015. Doi: 10.1029/2006JC003486

Kantha L, Rojsiraphisal T, Lopez J (2008) The North Indian Ocean circulation and its variability as seen in a numerical hindcast of the years 1993-2004. Progr Oceanogr 76:111-147

Karmovskaya ES (1992) New species of conger eel (Congridae) from the western Indian Ocean. J Ichthyol 32(3):891-897

Ma T (2006) Morphological variation and evolution of larval characteristics of congrid leptocephali in the Indo-Pacific region. PhD dissertation. University of Tokyo, Japan

Ma T, Aoyama J, Miller MJ, Minegishi Y, Inoue JG, Tsukamoto K (2008a) Genetic differentiation in the genus Uroconger in the Indo-Pacific region. Aquat Biol 2:29-35

Ma T, Miller MJ, Aoyama J, Minagawa G, Inoue JG, Watanabe S, Tsukamoto K (2008b) Genetic identification of two species of Ariosoma leptocephali. Coast Mar Sci 32:48-53

McCleave JD, Miller MJ (1994) Spawning of Conger oceanicus and Conger triporiceps (Congridae) in the Sargasso Sea and subsequent distribution of leptocephali. Environ Biol Fish 39:339-355 
Miller MJ (1995) Species assemblages of leptocephali in the Sargasso Sea and Florida Current. Mar Ecol Progr Ser 121:11-26

Miller MJ (2002a) Distribution and ecology of Ariosoma balearicum (Congridae) leptocephali in the western North Atlantic. Environ Biol Fish 63:235-252

Miller MJ (2002b) Contrasting migratory strategies of marine and freshwater eels. Fish Sci 68(Supplement 1):37-40

Miller MJ (2009) Ecology of anguilliform leptocephali: remarkable transparent fish larvae of the ocean surface layer. Aqua-BioSci Monogr 2(4):1-94

Miller MJ, McCleave JD (1994) Species assemblages of leptocephali in the subtropical convergence zone of the Sargasso Sea. J Mar Res 52:743-772

Miller MJ, Tsukamoto K (2004) An introduction to leptocephali: biology and identification. Ocean Research Institute, University of Tokyo, Tokyo

Miller MJ, Otake T, Minagawa G, Inagaki T, Tsukamoto K (2002) Distribution of leptocephali in the Kuroshio current and East China Sea. Mar Ecol Progr Ser 235:279-238

Miller MJ, Aoyama J, Mochioka N, Otake T, Castle PHJ, Minagawa G, Inagaki T, Tsukamoto K (2006a) Geographic variation in the assemblages of leptocephali in the western South Pacific. Deep-Sea Res I 53:776-794

Miller MJ, Wouthuyzen S, Minagawa G, Aoyama J, Tsukamoto K (2006b) Distribution and ecology of leptocephali of the congrid eel, Ariosoma scheelei, around Sulawesi Island, Indonesia. Mar Biol 148:1101-1111

Miller MJ, Wouthuyzen S, Ma T, Aoyama J, Suharti SR, Minegishi Y, Tsukamoto K (2011a) Distribution, diversity and abundance of garden eel leptocephali off west Sumatra, Indonesia. Zool Stud 50:177-191

Miller MJ, Yoshinaga T, Aoyama J, Otake T, Mochioka N, Kurogi H, Tsukamoto K (2011b) Offshore spawning of Conger myriaster in the western North Pacific: evidence of convergent migration strategies of anguilliform eels in the Atlantic and Pacific. Naturwissenshaften 98:537-543

Miller MJ, Stepputtis D, Bonhommeau S, Castonquay M, Schaber M, Vobach M, Hanel R (2013) Comparisons of catches of large leptocephali using an IKMT and a large pelagic trawl in the Sargasso Sea. Mar Biodiv. Doi: 10.1007/ s12526-013-0170-7

Mochioka N, Kakuda S, Tabeta O (1982) Congrid leptocephali in the western North and Middle Pacific I: exterilium Ariosoma-type larvae. J Faculty Appl Biol Sci Hirosh Univ 21:35-66

Mochioka N, Tabeta O, Kakuda S, Tsukahara H (1991) Congrid leptocephali in the western north and middle Pacific II. Non-exterilium Ariosoma type larvae. Bull Mar Sci 48:606-622

Moyer JT, Zaiser MJ (1982) Reproductive behavior of moray eels at Miyake-jima, Japan. J Ichthyol 28:466-468

Sengupta D, Senan R, Goswami BN, Vialard I (2007) Intraseasonal variability of equatorial Indian Ocean zonal currents. J Climate 20:3036-3055

Smith DG (1989a) Family Congridae: leptocephali. In: Böhlke EB (ed) Fishes of the western North Atlantic. Part 9, vol. 2. Sears Foundation for Marine Research, New Haven, CT, pp 723-763

Smith DG (1989b) Family Congridae. In: Böhlke EB (ed) Fishes of the western North Atlantic. Part 9, vol. 1. Sears Foundation for Marine Research, New Haven, $C T$, pp 460-567

Smith DG, Karmovskaya ES (2003) A new genus and two new species of congrid eels (Teleostei: Anguilliformes: Congridae) from the Indo-West Pacific, with a redescription and osteology of Chiloconger dentatus. Zootaxa 343:1-19

Strehlow B, Antunes C, Niermann U, Tesch F-W (1998) Distribution and ecological aspects of leptocephali collected 1979-1994 in North and Central Atlantic. I. Congridae. Helgoländer Meeresunters 52:85-102

Susanto RW, Gordon AL, Zheng Q (2001) Upwelling along the coasts of Java and Sumatra and its relation to ENSO. Geophys Res Lett 28:1599-1602

Tabeta O, Mochioka N (1988) Leptocephali. In: Okiyama M (ed) An atlas of the early stage fishes in Japan. Tokai University Press, Tokyo, pp 15-64 (in Japanese)

Thompson B, Gnanaseelan C, Salvekar PS (2006) Variability in the Indian Ocean circulation and salinity and its impact on SST anomalies during dipole events. J Mar Res 6:853-880

Thresher RE (1984) Reproduction in reef fishes. Tropical Fish Hobbyist Publications, Neptune City, N.

Vinayachandran PN, Masumoto Y, Mikawa T, Yamagata T (1999) Intrusion of the Southwest Monsoon Current into the Bay of Bengal. J Geophys Res 104:11077-11085

Vranes K, Gordon AL, Ffield A (2002) The heat transport of the Indonesian throughflow and implications for the Indian Ocean heat budget. Deep Sea Res || 49:1391-1410
Walsh HJ, Marancik KE, Hare JA (2006) Juvenile fish assemblages collected on unconsolidated sediments of the southeast United States continental shelf. Fish Bull 104:256-277

Wouthuyzen S, Miller MJ, Aoyama J, Minagawa G, Sugeha YH, Suhartati S, Inagaki T, Tsukamoto K (2005) Biodiversity of anguilliform leptocephali in the central Indonesian Seas. Bull Mar Sci 77:209-224

Wyrtki K (1961) Physical oceanography of the Southeast Asian waters. NAGA Report 2. Scripps Institution of Oceanography, La Jolla, CA, p 195

doi:10.1186/1810-522X-52-26

Cite this article as: Miller et al: Ariosoma-type Leptocephali (Congridae: Bathymyrinae) in the Mentawai Islands region off western Sumatra, Indonesia. Zoological Studies 2013 52:26.

\section{Submit your manuscript to a SpringerOpen ${ }^{\circ}$ journal and benefit from:}

- Convenient online submission

- Rigorous peer review

- Immediate publication on acceptance

- Open access: articles freely available online

- High visibility within the field

- Retaining the copyright to your article

Submit your next manuscript at $\gg$ springeropen.com 